Brit. J. vener. Dis. (1960), 36, 145.

EDITORIAL

\title{
THE CONTROL OF HUMAN TRICHOMONIASIS
}

It is 124 years since Alfred Donné reported his discovery of the flagellate, now known as Trichomonas vaginalis, in the vaginal discharge of a woman suffering from vaginitis (Donné, 1836). During the succeeding decades a multiplicity of treatments, most of them local applications, has been given for this infestation. The value of local therapy is, however, probably limited by the ability of the trichomonads to persist in sites other than the vagina, thus escaping contact with the drug, and to reinvade the vagina when conditions there are again favourable for their survival. It is axiomatic that, however potent a trichomonicidal substance may be, its effectiveness depends on its ability to reach all the seats of infestation. This indicates the necessity for a systemic trichomonicide, non-toxic to the patient and capable of reaching all the tissues of the urogenital tract. There is now clear evidence that in "Flagyl" an effective systemic cure for trichomoniasis has been found. Here the cautionary note must be sounded that freedom from toxic effects will be confirmed only by long and carefully evaluated experience of the drug.

Durel, Roiron, Siboulet, and Borel (1960) initiated the study of 8823 R.P. ("Flagyl")) in the treatment of trichomoniasis. On May 27, 1960, at a meeting of the Medical Society for the Study of Venereal Diseases, further detailed studies of the use of "Flagyl" by mouth in the treatment of trichomoniasis were presented by King and Rodin (p. 147) and by Nicol (p. 152). These workers showed that the drug was highly effective and that toxic reactions were few. During the subsequent discussion these findings were confirmed by other speakers, including Durel (p. 154).

As pointed out by Willcox (p. 160), this meeting was a landmark and recalled those following the introduction of sulphonamides and of penicillin. It appears that trichomoniasis has now joined the growing list of conditions which are easier to treat than to diagnose. It is to be hoped that the drug will be used with discrimination, that infestations resistant to its action will be fully investigated, and that fundamental studies, both of $T$. vaginalis and of the sites affected by it will be continued.

The remarkable effectiveness of orally administered "Flagyl", even in long-standing cases of vaginal trichomoniasis, focuses attention on the small number of patients who have not responded to this form of therapy. Are these failures due to the resistance of certain "strains" of $T$. vaginalis to "Flagyl", to the inability of the host to absorb a sufficient amount of the drug, or to the survival of a few flagellates for long enough to initiate a relapse when treatment is stopped? Information on these questions might help in devising even more effective forms of treatment for this often distressing condition. It may be that the introduction of "Flagyl" will be followed by that of other systemic trichomonicides and this would be a welcome development.

Fundamental studies should not be neglected as many questions remain unanswered. Why is the infestation symptomless in some men and women? Is this due to strains of different virulence or to resistance in the host? If the latter, are local factors responsible and why do patients with latent infestations suddenly develop symptoms? Which are the sites affected in the male? Does a true trichomonal urethritis occur in men or is the organism a secondary invader? Does infestation cause inflammation of the pelvic organs in women?

Most cases of trichomoniasis are acquired by sexual intercourse and it is now recognized that the sexual partners should always be examined and, if necessary, treated. Moreover, the management of any case of trichomoniasis entails the exclusion of other diseases that may be transmitted by sexual intercourse. It is an advantage if both partners are seen by the same doctor and, clearly, the special interests, training, and experience of the venereologist particularly fit him for this task.

In discussing trichomoniasis, it seems advisable to many that the term "venereal disease" should be avoided. Although the infestation is acquired by 
sexual intercourse in most cases, it is not "V.D." in the restricted sense to which the public are accustomed. Many venereologists deem it wise to make this distinction very clear to their patients by explaining that the infestation is a simple "inflammation" which may be passed on by intercourse. Although this attitude may not be entirely logical it is eminently practical and has much to recommend it in that it avoids unnecessary distress and recriminations.

\section{REFERENCES}

Donné, A. (1836). C.R. Acad. Sci., Paris, 3, 385.

Durel, P., Roiron, V., Siboulet, A., and Borel, L. J. (1960). Brit. J. vener. Dis., 36, 21.

\section{Editorial}

Il y a 124 ans qu'Alfred Donné a rapporté sa découverte, dans l'écoulement vaginal d'une femme atteinte de vaginite, des flagellés portant aujourd'hui le nom de Trichomonas vaginalis (Donné, 1836). Au cours des dizaines d'années successives d'innombrables traitements, surtout locaux, ont été administrés contre cette infestation. Cependant, la valeur d'une thérapie locale est peut-être limitée par la capacité des trichomonades de survivre aux endroits autres que le vagin, d'éviter ainsi le contact avec le médicament et de réinfester le vagin en conditions redevenues plus favorables. C'est un axiome que, quelque soit le pouvoir trichomonicide d'une substance, son efficacité depend de sa capacité d'atteindre tous les sièges d'infestation. Cela implique le besoin d'un trichomonicide à action générale, non toxique et capable d'atteindre tous les tissus des voies génito-urinaires. On vient de recevoir des preuves concluantes que "Flagyl" est un moyen efficace par voie générale contre la trichomoniase. Un avertissement est toutefois nécessaire: pour confirmer l'inocuité de ce médicament, on a encore besoin d'une évaluation longue et soigneuse en pratique.

Durel, Roiron, Siboulet et Borel (1960) ont commencé l'étude du 8823 R.P. ("Flagyl") dans le traitement de la trichomoniase. Le 27 mai 1960, à la réunion de la Société Médicale pour l'Etude des Maladies Vénériennes, d'autres rapports détaillés sur l'emploi du "Flagyl" par voie buccale dans le traitement de la trichomoniase ont été présentés par King et Rodin (p. 147) et par Nicol (p. 152). Ces auteurs ont démontré que ce médicament est éminemment efficace et les réactions toxiques sont rares. Pendant la discussion qui s'est ensuivi, ces résultats ont été confirmés par d'autres participants, y compris Durel (p. 154).

Comme Willcox (p. 160) l'a signalé, cette réunion était un événement mémorable, rappellant des occasions semblables lors de l'introduction des sulfamides et de la pénicilline. Il semble que la trichomoniase vient de s'ajouter au nombre croissant des affections dont le traitement est plus facile que le diagnostic. Il est à espérer, qu'on se servira de ce médicament d'une manière judicieuse, que les infestations résistantes à son action seront examinées à fond et que les études essentielles du $T$. vaginalis et de son habitat seront continuées.

L'efficacité remarquable du "Flagyl" administré par voie orale, même dans des cas de trichomoniase vaginale ancienne, met en relief ce petit nombre de malades qui n'ont pas réagi à cette forme de thérapie. Ces insuccès, sont-ils dus à la résistance de certaines "souches" du $T$. vaginalis au "Flagyl", à l'incapacité de l'hôte d'absorber une quantité suffisante du médicament, ou à la survie de quelques flagellés pendant un temps assez long pour permettre une rechute lorsqu'on arrête le traitement? Des renseignements sur ces questions pourraient aider à imaginer des formes de traitement encore plus efficaces de cette affection, souvent très affligeante. Il est possible que "Flagyl" sera suivi de la découverte d'autres trichomonicides généraux, ce qui serait un développement très désirable.

Des recherches essentielles ne doivent pas être négligées, car beaucoup de questions demeurent sans réponse. Comment se fait-il, que l'infestation est asymptomatique chez certains hommes et femmes? Est-ce parce que certaines souches ont une virulence différente ou bien l'hôte est plus résistant? Dans ce dernier cas, s'agit-il de facteurs locaux? Pourquoi les malades à infestation latente manifestent soudainement des symptômes? Quels sont les endroits affectés chez le mâle? Une vraie urétrite à trichomonas, survient-elle chez l'homme, ou s'agit-il ici d'une invasion secondaire? Est-ce que l'infestation provoque une inflammation des organes du bassin feminin?

La plupart des cas de trichomoniase s'acquiert par le rapport sexuel et on reconnaît aujourd'hui que le partenaire sexuel doit toujours être examiné et, si nécessaire, traité. De plus, chaque cas de trichomoniase implique l'exclusion diagnostique d'autres maladies susceptibles d'être transmises par voie sexuelle. Il est préférable que le deux partenaires soient vus par le même médecin et, évidemment, les intérêts spéciaux, l'instruction et l'expérience du vénéréologue en font la personne la plus indiqueé pour cette tâche.

En parlant de la trichomoniase, il y en a qui pensent que le terme "maladie vénérienne' devrait être évité. Bien que dans la plupart des cas l'infestation est acquise par voie sexuelle, elle n'est pas une "maladie vénérienne" dans le sens restreint de cette expression, telle que le public général l'entend. Beaucoup de vénéréologues considèrent qu'il est prudent de faire cette distinction et d'expliquer à leurs malades que l'infestation est une simple "inflammation" qui peut être transmise par le rapport sexuel. Bien que cette attitude ne soit pas tout à fait logique, elle est éminemment pratique et possède le grand avantage de prévenir une détresse et des récriminations peu nécessaires. 